\title{
Characterization of a Host-Specific Protein Toxin (Ptr ToxB) from Pyrenophora tritici-repentis
}

\author{
Stephen E. Strelkov, Lakhdar Lamari, and G. Murray Ballance \\ Department of Plant Science, University of Manitoba, Winnipeg, MB, Canada, R3T 2N2 \\ Accepted 9 April 1999.
}

\begin{abstract}
Pyrenophora tritici-repentis, the causal agent of tan spot of wheat, differentially induces tan necrosis and/or chlorosis in wheat. A chlorosis-inducing, host-specific toxin, termed Ptr ToxB (formerly Ptr chlorosis toxin), was purified from the culture filtrates of a race 5 isolate of $P$. tritici-repentis. Partial purification was performed by 25 to $80 \%$ ammonium sulfate precipitation and passage through a carboxymethyl-Sephadex C-25 cation exchange column. Final purification was performed by fast performance liquid chromatography, with a Mono S HR 5/5 cation exchanger, followed by size fractionation on a Superose 12 HR 10/30 column. The toxin was shown to be proteinaceous in nature, and purity was confirmed by sodium dodecyl sulfate-polyacrylamide gel electrophoresis. The molecular mass of Ptr ToxB was determined to be $6.61 \mathrm{kDa}$. The amino acid composition and partial $N$ terminus amino acid sequence of the toxin were also obtained. Ptr ToxB was found to be heat stable, maintaining full toxic activity after $1 \mathrm{~h}$ at $55^{\circ} \mathrm{C}$. Infiltration of toxin concentrations as low as $14 \mathrm{nM}$ produced chlorosis on susceptible cultivars.
\end{abstract}

Additional keywords: Ptr necrosis toxin, Ptr ToxA, Triticum aestivum $\mathrm{L}$.

Tan spot, caused by Pyrenophora tritici-repentis (Died.) Drechs., anamorph Drechslera tritici-repentis (Died.) Shoemaker, is an important foliar disease of wheat (Triticum aestivum L.) worldwide. The incidence of this disease has been increasing in recent years, as a consequence of the shift by farmers toward soil conservation practices such as minimum and zero tillage (Hosford 1982). Tan spot consists of two distinct symptoms: tan necrosis and extensive chlorosis (Lamari and Bernier 1989a, 1989b). Five races of the fungus have been described so far, producing necrosis and/or chlorosis on differential wheat cultivars (Lamari et al. 1995). Race 1 isolates are capable of producing both necrosis and chlorosis, race 2 isolates can only produce the necrotic symptom, race 3 and race 5 isolates both cause chlorosis, but on different cultivars, and race 4 isolates are avirulent, producing neither symptom (Lamari et al. 1995).

The necrotic symptom was shown to be associated with a host-specific toxin, termed Ptr ToxA (formerly Ptr necrosis toxin) (Lamari and Bernier 1989c). Ptr ToxA, a 13.2-kDa protein, has been characterized by several independent research groups and its encoding gene was recently cloned

Corresponding author: L. Lamari; E-mail: L_Lamari@umanitoba.ca
(Ballance et al. 1996; Ciuffetti et al. 1997). This toxin exhibits the same host specificity as the isolates from which it is obtained, and has been recognized as an important factor in the development of the tan spot disease (Tomás and Bockus 1987; Ballance et al. 1989; Lamari and Bernier 1991).

A second host-specific toxin, termed Ptr ToxB (formerly Ptr chlorosis toxin), was identified from a race 5 isolate of $P$. tritici-repentis (Orolaza et al. 1995). The toxin is a pathogenicity factor, and preliminary characterization of Ptr ToxB suggested that it was a small, hydrophilic protein, stable to exposure to organics (Orolaza et al. 1995; Strelkov et al. 1998). Although partial results on the purification of Ptr ToxB were presented previously (Strelkov et al. 1998), the present work describes the purification and characterization of the toxin from culture filtrate of race 5 isolate Alg. 3-24 of $P$. tritici-repentis.

\section{RESULTS}

\section{Purification.}

Toxic activity in the culture filtrate was associated with protein precipitated at 25 to $80 \%$ ammonium sulfate saturation. The precipitate was redissolved, dialyzed, and loaded onto a carboxymethyl-Sephadex (CM-S) C-25 column. The unbound fraction was strongly UV-absorbing and possessed no toxic activity. The elution profile indicated that toxic activity was eluted at approximately $300 \mathrm{mM} \mathrm{NaCl}$ (results not shown). Electrophoretic analysis of the toxic fractions showed the presence of three major and several minor proteins (Fig. 1). The toxic fractions were concentrated, desalted, and fractionated on a fast performance liquid chromatography (FPLC) Mono S HR 5/5 column by gradient elution, as described in Materials and Methods. The elution profile (Fig. 2) indicated four major peaks (labeled I, II, III, and IV) but toxic activity was only associated with peaks II and III, with peak II possessing the strongest activity. Sodium dodecyl sulfatepolyacrylamide gel electrophoresis (SDS-PAGE) of peaks I to IV (Fig. 3) revealed that both peaks II and III contained strong bands of less than $6.5 \mathrm{kDa}$, plus a weaker band of approximately $27 \mathrm{kDa}$. However, the lower molecular mass band was more highly enriched in peak II than in peak III. Peaks II and III were pooled, desalted, concentrated, and partitioned with an FPLC Superose 12 HR 10/30 column (Fig. 4). The toxin, corresponding to a single UV-280 absorbing peak, was separated from two visible contaminants. SDS-PAGE of the pooled fraction revealed only one Coomassie blue stained band of approximately $6 \mathrm{kDa}$ (Fig. 5). Symptoms produced by 
the purified toxin on sensitive (Katepwa) and insensitive (Glenlea) wheat leaves are shown in Figure 6. The protein recovery during the various purification steps is shown in Table 1. The total Ptr ToxB recovered accounted for $0.0123 \%$ of the total soluble protein present in the crude culture filtrate.

\section{Molecular mass determination, amino acid composition, and sequence.}

The molecular mass of Ptr ToxB was determined to be $6,612 \pm 7 \mathrm{Da}(0.1 \%$ error $)$ by mass spectrometry. The matrixassisted laser desorption/ionization time-of-flight (MALDI-

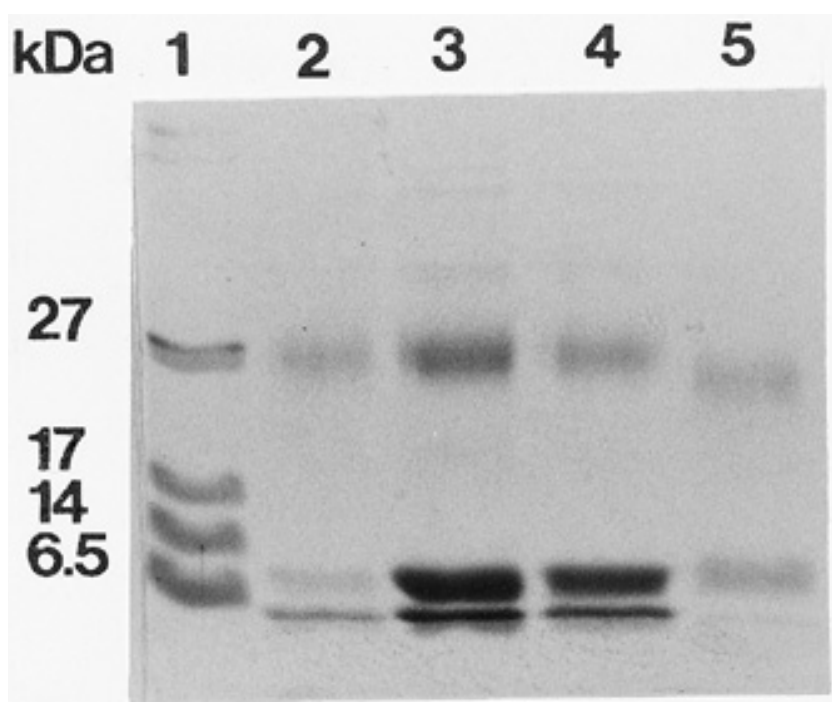

Fig. 1. Sodium dodecyl sulfate-polyacrylamide gel electrophoresis (SDS-PAGE) of toxic fractions eluted from CM-S C-25 chromatography with a linear gradient of $\mathrm{NaCl}$ (0 to $400 \mathrm{mM}$ ). Lane 1: molecular weight markers $(10 \mu \mathrm{g}$ of total protein). Lanes 2 to 5 :, toxic fractions corresponding to fractions 20 to 23 from CM-S C-25 chromatography (1.5, $13.8,8.4$, and $0.93 \mu \mathrm{g}$ of protein loaded, respectively). The fractions in lanes 3 and 4 had the strongest toxic activity.

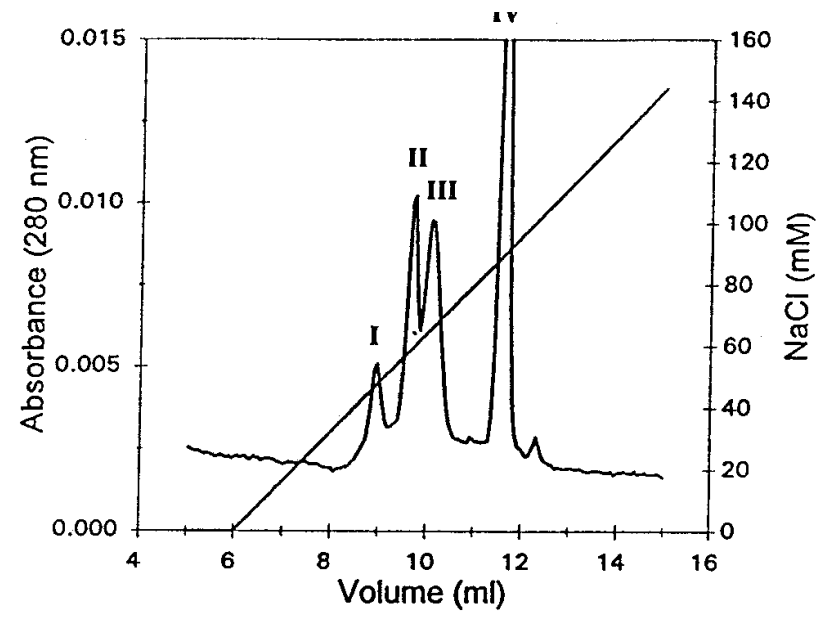

Fig. 2. Mono $S$ chromatography of Ptr ToxB. Fractions exhibiting toxic activity after CM-S C-25 chromatography were pooled and loaded onto a Mono S HR 5/5 column. Column was eluted with a linear gradient of 0 to $400 \mathrm{mM} \mathrm{NaCl}$ in $20 \mathrm{mM} \mathrm{NaAc}$ (pH 4.6) over 25 column volumes. Eluate was monitored at $280 \mathrm{~nm}$ and fractions were bioassayed for toxic activity. Peaks were labeled as I, II, III, and IV. Only II and III contained toxic activity.
TOF) mass spectrum of the toxin is shown in Figure 7. The amino acid composition of Ptr ToxB is presented in Table 2. After correction for cysteine and methionine underestimation, and glycine overestimation, Ptr ToxB appeared to have 63 residues and a molecular mass of 6,609 Da. The partial amino acid sequence of the $\mathrm{N}$ terminus of Ptr ToxB was determined to be NXVANILNINEAVIATGSVPAGGELRIFVG.

\section{Thermal stability.}

The thermal stability of the toxic activity was determined after several heat-period treatments. Activity was fully present after heating for $60 \mathrm{~min}$ at 30,40 , and $55^{\circ} \mathrm{C}$. Slightly weaker activity was still present after $30 \mathrm{~min}$ at $80^{\circ} \mathrm{C}$, and a low level

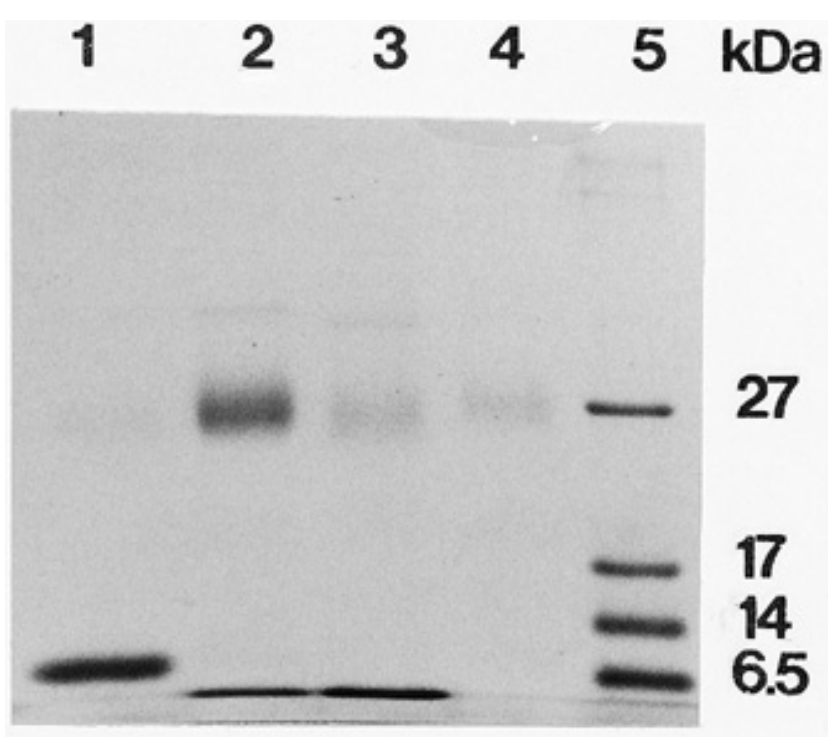

Fig. 3. Sodium dodecyl sulfate-polyacrylamide gel electrophoresis (SDS-PAGE) of fractions from Mono $\mathrm{S}$ chromatography. Lane 1: $5.8 \mu \mathrm{g}$ of protein from peak IV; lane 2; $3.8 \mu \mathrm{g}$ of protein from peak III; lane 3: $3.5 \mu \mathrm{g}$ of protein from peak II; lane 4: $0.25 \mu \mathrm{g}$ of protein from peak I; lane 5: molecular weight markers (10 $\mu \mathrm{g}$ of total protein). Only fractions in lanes 2 and 3 possessed toxic activity.

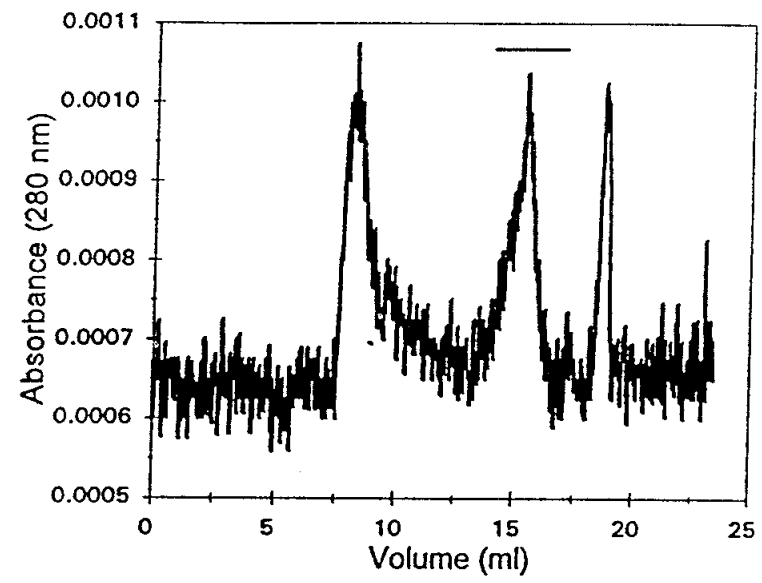

Fig. 4. Superose 12 chromatography of Ptr ToxB. Peaks II and III from MonoS HR 5/5 chromatography were pooled, concentrated, and loaded onto a Superose $12 \mathrm{HR}$ 10/30 column. Column was eluted with $20 \mathrm{mM}$ $\mathrm{NaAc}$ buffer, $\mathrm{pH} 4.6$, at $0.5 \mathrm{ml} / \mathrm{min}$. Eluate was monitored at $280 \mathrm{~nm}$ and fractions were bioassayed for toxic activity. The toxic fraction, corresponding to Ptr ToxB, is indicated with the solid bar. 


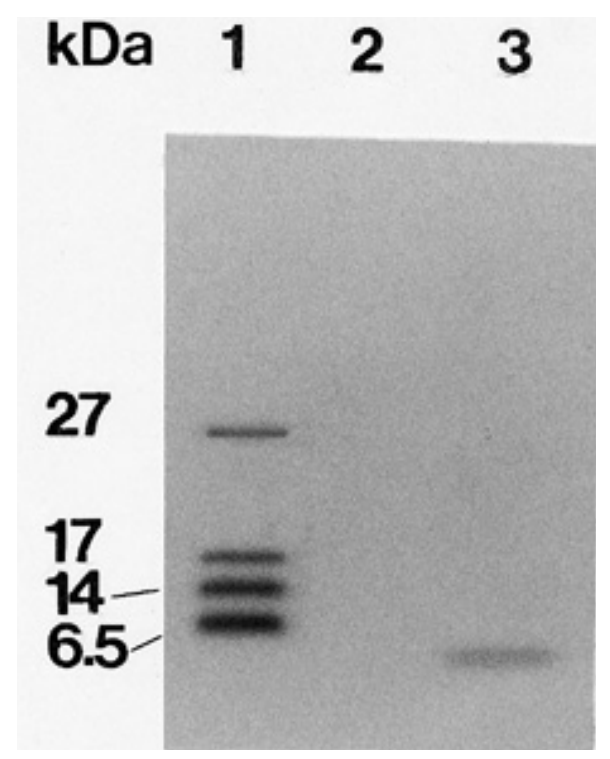

Fig. 5. Sodium dodecyl sulfate-polyacrylamide gel electrophoresis (SDS-PAGE) of purified Ptr ToxB. Lane 1: molecular weight markers (10 $\mu \mathrm{g}$ of total protein); lane 2: empty; lane 3: purified Ptr ToxB (0.8 $\mu \mathrm{g})$ obtained from Superose 12 HR 10/30 chromatography.

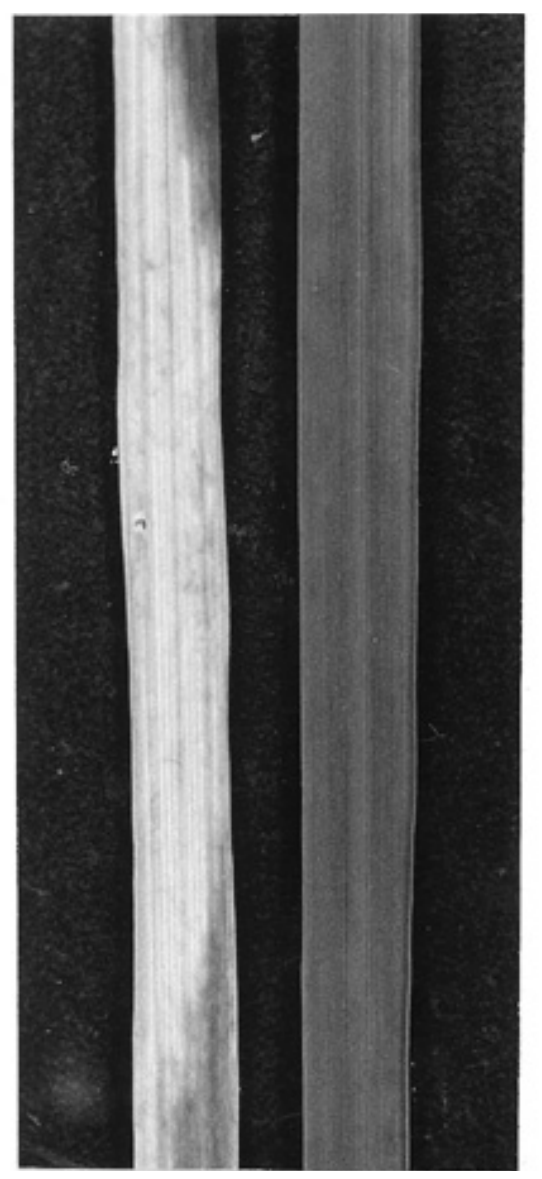

Fig. 6. Symptoms produced by Ptr ToxB. Leaves from toxin-sensitive cv. Katepwa (left) and toxin-insensitive cv. Glenlea (right), shown $72 \mathrm{~h}$ after infiltration with purified Ptr ToxB (at a concentration of $9.5 \mu \mathrm{g} / \mathrm{ml}$ ). of chlorosis was detectable after $60 \mathrm{~min}$ at $80^{\circ} \mathrm{C}$. A trace level of chlorosis was still detectable after 30 and $60 \mathrm{~min}$ of heating at $100^{\circ} \mathrm{C}$.

\section{Effect of toxin concentration on toxic activity.}

The activity of the purified toxin was detectable by the bioassay procedure, described in Materials and Methods, at a toxin concentration of $95 \mathrm{ng} / \mathrm{ml}(14 \mathrm{nM})$. At this concentration, chlorosis, although weak, was visible within $72 \mathrm{~h}$ post infiltration. Symptoms of chlorosis were readily apparent within $48 \mathrm{~h}$ post infiltration when the toxin was applied at 10 , 100 , and 1,000 times this concentration. By $96 \mathrm{~h}$ post infiltration, tissue treated with toxin solutions of 95 or $9.5 \mu \mathrm{g} / \mathrm{ml}$ had begun to die at the center of the infiltrated area; tissue infiltrated with $0.95 \mu \mathrm{g} / \mathrm{ml}$, although severely chlorotic, had not developed any necrosis. Toxin applied at $9.5 \mathrm{ng} / \mathrm{ml}$ failed to produce chlorosis at any time. The toxin-insensitive cv. Glenlea was tested with the same range of toxin concentrations, but symptoms did not develop at any of the concentrations tested.

\section{DISCUSSION}

Earlier work indicated that Ptr ToxB was a hydrophilic molecule, stable to exposure to organics, with a molecular mass of at least $3.5 \mathrm{kDa}$ (Orolaza et al. 1995). The present investigation conclusively showed that the toxin is a protein with a molecular mass of $6.61 \mathrm{kDa}$. Ptr ToxB stained and bound to chromatogra-

Table 1. Protein content at various steps of the purification procedure developed for Ptr ToxB

\begin{tabular}{lcc}
\hline Step & $\begin{array}{c}\text { Protein content } \\
(\mathbf{m g})\end{array}$ & $\begin{array}{c}\text { Total soluble } \\
\text { protein }(\%)\end{array}$ \\
\hline Concentrated culture filtrate & $1.51 \times 10^{3}$ & 100 \\
25 to $80 \%\left(\mathrm{NH}_{4}\right)_{2} \mathrm{SO}_{4}$ ppt & $2.16 \times 10^{2}$ & 14.3 \\
$\mathrm{CM}-\mathrm{S} \mathrm{C}-25$ toxic fractions & 9.04 & 0.598 \\
Mono S 5/5 toxic fractions & 0.359 & 0.0237 \\
Superose 12 toxic fractions & 0.186 & 0.0123 \\
\hline
\end{tabular}

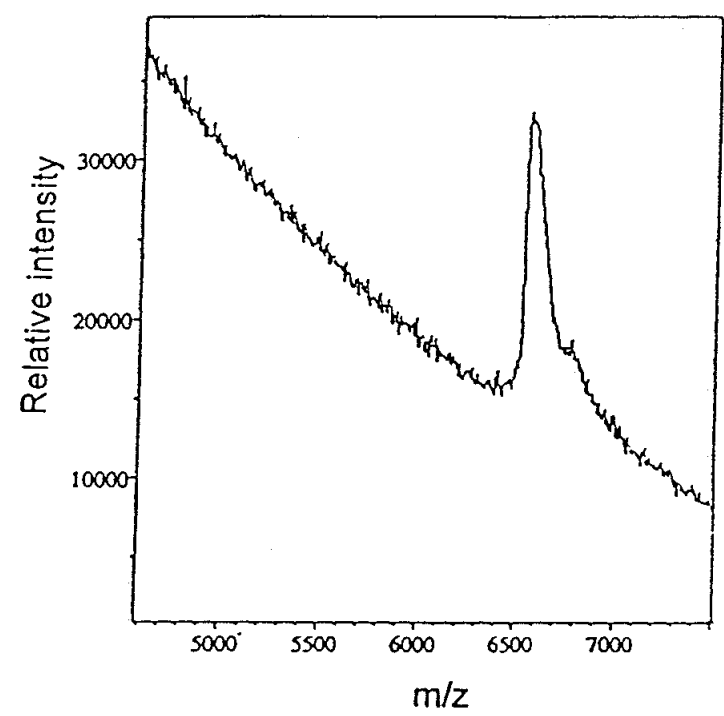

Fig. 7. Matrix-assisted laser desorption/ionization time-of-flight (MALDI-TOF) mass spectrum of Ptr ToxB. Spectrum was obtained from a sample of toxin deposited onto a polyurethane membrane. The peak corresponds to a molecular mass of $6,612 \pm 7 \mathrm{Da}$. 
phy columns in a manner consistent with a protein; the toxin was purified to homogeneity by conventional protein purification techniques. Most importantly, an amino acid composition (Table 2) and partial amino acid sequence were obtained for Ptr ToxB, further confirming its protein nature.

Attempts to estimate the concentration of Ptr ToxB based on the absorbance of toxin solutions at $280 \mathrm{~nm}$ invariably resulted in underestimations of its concentration, compared with values obtained with the Lowry assay and with band intensity on SDS-polyacrylamide gels. This suggested that Ptr ToxB may not contain any tryptophan residues, since $280 \mathrm{~nm}$ is the absorption maximum of tryptophan (Haurowitz 1963). Furthermore, the partial amino acid sequence of the toxin protein revealed no tryptophan residues among the 30 residues successfully sequenced. Hence, even though tryptophan is completely destroyed during acid hydrolysis prior to running on an amino acid analyzer, there appear to be no tryptophan residues in Ptr ToxB. Consequently, tryptophan was not incorporated into the corrected amino acid composition of the toxin (Table 2).

Ptr ToxB appears to be heat stable. There was no reduction in toxic activity after heating for $1 \mathrm{~h}$ at $55^{\circ} \mathrm{C}$, conditions that resulted in the irreversible denaturation of Ptr ToxA (Ballance et al. 1989). After $1 \mathrm{~h}$ at $100^{\circ} \mathrm{C}$, some toxic activity was still present. Since we did not have a way to monitor the change of structure of the toxin following heating, it is not clear whether this thermal stability was due to an inability of the heat to disrupt the functional site, or if the small nature of the protein made it difficult to denature. It is also possible that the toxin renatured after cooling. In addition, Ptr ToxB had a very high level of toxic activity, with a minimum active concentration of $14 \mathrm{nM}$.

An unusual aspect of $P$. tritici-repentis is its production of host-specific toxins that are proteinaceous in nature; Ptr ToxA is a 13.2-kDa protein (Tuori et al. 1995) and Ptr ToxB is a $6.61-\mathrm{kDa}$ protein. All other known host-specific toxins are secondary metabolites with diverse structures and low molecular masses (Walton 1996). Aside from the fact that Ptr ToxA and Ptr ToxB are proteins and are host specific, they

Table 2. Amino acid composition of Ptr ToxB isolated from culture filtrate of Pyrenophora tritici-repentis isolate Alg. 3-24

\begin{tabular}{lccc}
\hline Amino acid & $\begin{array}{c}\text { Actual amount } \\
(\mathbf{p m o l})\end{array}$ & $\begin{array}{c}\text { Corrected } \\
\text { amount }(\mathbf{p m o l})^{\mathbf{a}}\end{array}$ & $\begin{array}{c}\text { Predicted residue } \\
\text { composition }^{\mathbf{b}}\end{array}$ \\
\hline Asp + Asn & 288 & 288 & 5 \\
Glu + Gln & 276 & 276 & 5 \\
Ser & 345 & 400 & 8 \\
Gly & 411 & 250 & 5 \\
His & 51 & 51 & 1 \\
Arg & 104 & 104 & 2 \\
Thr & 212 & 212 & 4 \\
Ala & 320 & 320 & 6 \\
Pro & 131 & 131 & 3 \\
Tyr & 74 & 100 & 2 \\
Val & 260 & 260 & 5 \\
Met & 20 & 40 & 1 \\
Cys & 65 & 130 & 2 \\
Ile & 234 & 250 & 5 \\
Leu & 273 & 273 & 5 \\
Phe & 119 & 119 & 2 \\
Lys & 99 & 99 & 2 \\
Total & 3,282 & 3,303 & 63 \\
Molecular mass & & & $6,609 \mathrm{Da}$ \\
\hline
\end{tabular}

\footnotetext{
${ }^{\text {a }}$ Corrected for amino acids that were over- or underestimated.
}

${ }^{\mathrm{b}}$ Predicted on the basis of a molecular mass of 6,612 Da. have very little in common: they induce different types of symptoms, and a screening of genomic DNA from the Alg. 324 isolate with the full-length cDNA clone of Ptr ToxA yielded no complementary matches (Ballance et al. 1996). This difference in sequences was confirmed by partial $\mathrm{N}$ terminus amino acid sequencing of Ptr ToxB, which revealed no sequence homology with Ptr ToxA. The mode of action of Ptr ToxB remains the focus of other studies (Strelkov et al. 1998).

\section{MATERIALS AND METHODS}

\section{Isolates and fungal cultures.}

Race 5 isolate Alg. 3-24 of P. tritici-repentis used in this investigation is a laboratory stock that was previously collected from Algeria (Lamari et al. 1995). Cultures of this isolate were grown on V8 potato dextrose agar (Lamari and Bernier 1989a) until they were 4 to $5 \mathrm{~cm}$ in diameter. Five plugs $(1 \mathrm{~cm}$ in diameter) were cut from each colony and transferred to 1liter Roux bottles, each containing $250 \mathrm{ml}$ of Fries medium amended with $0.1 \%$ yeast extract (Dhingra and Sinclair 1986). The cultures were incubated without agitation at $20^{\circ} \mathrm{C}$ for 21 days. The filtrates were removed from the mycelial mat by filtering through Whatman No. 1 filter paper and $0.45-\mu \mathrm{m}$ cellulose nitrate filters. Culture filtrates were freeze dried and stored at $-20^{\circ} \mathrm{C}$ until processed.

\section{Plant materials and bioassays.}

Wheat cultivars Katepwa (sensitive to Ptr ToxB) and Glenlea (insensitive to Ptr ToxB) were used throughout the study. The seedlings were grown in plastic pots $(12 \mathrm{~cm}$ in diameter) filled with a $1: 1$ soil/peat mix at a density of five to six seedlings per pot. The plants were maintained in a growth room at $22 / 18^{\circ} \mathrm{C}$ (day/night) with a $16-\mathrm{h}$ photoperiod at a light intensity of $250 \mu \mathrm{E} \mathrm{s}^{-1} \mathrm{~m}^{-2}$. Seedlings were watered and fertilized as required. Bioassays were conducted by infiltrating seedlings at the two- to four-leaf stage with approximately $20 \mu \mathrm{l}$ of sample, using a Hagborg device (Hagborg 1970).

\section{Toxin purification.}

Approximately 2 liters of culture filtrate was freeze dried to give approximately $20 \mathrm{~g}$ of dry matter. Freeze-dried culture filtrate was resuspended in $40 \mathrm{ml}$ of $20 \mathrm{mM}$ sodium acetate buffer (pH 4.6) containing $100 \mu \mathrm{M}$ phenylmethylsulfonyl fluoride (PMSF). The resuspended culture filtrate was centrifuged at $17,400 \times g$ for $10 \mathrm{~min}$ and the supernatant retained. Sequential salt fractionation of the protein in the supernatant was conducted with ammonium sulfate in two steps. Material precipitating out at 0 to $25 \%$ salt saturation was discarded, and that precipitating out at 25 to $80 \%$ saturation was retained. The precipitate was redissolved in $30 \mathrm{ml}$ of $20 \mathrm{mM}$ sodium acetate buffer $(\mathrm{pH} 4.6)$ containing $100 \mu \mathrm{M}$ PMSF, and dialyzed against the same buffer. The dialyzed sample was loaded onto a CM-Sephadex C-25 column $(19 \times 2.5 \mathrm{~cm})$ equilibrated with $20 \mathrm{mM}$ sodium acetate buffer ( $\mathrm{pH}$ 4.6) containing $100 \mu \mathrm{M}$ PMSF. The unbound fraction was eluted by washing the column with 7 bed volumes of equilibration buffer. The bound fraction was then eluted with a 0 to $400 \mathrm{mM} \mathrm{NaCl}$ gradient ( $250 \mathrm{ml}$ of total volume) in equilibration buffer at a flow rate of $30 \mathrm{ml} / \mathrm{h}$. The eluate was collected in 9-ml fractions while monitored at $280 \mathrm{~nm}$. Toxic activity of the fractions was assessed following a 1/5 dilution with water by the bioassay procedure described above. Toxic fractions were 
pooled, concentrated by freeze drying, and dialyzed against 20 $\mathrm{mM}$ sodium acetate buffer ( $\mathrm{pH}$ 4.6). The dialysate was loaded onto an FPLC Mono S HR 5/5 column (Pharmacia, Baie d'Urfe, Quebec, Canada; column volume $=1 \mathrm{ml}$ ) equilibrated with 20 $\mathrm{mM}$ sodium acetate buffer ( $\mathrm{pH}$ 4.6). The bound proteins were fractionated with a linear gradient of 0 to $400 \mathrm{mM} \mathrm{NaCl}$ (in equilibration buffer) over 25 column volumes at $0.5 \mathrm{ml} / \mathrm{min}$. Toxic fractions were again pooled, dialyzed, freeze dried, and fractionated on an FPLC Superose 12 HR 10/30 column (Pharmacia; column volume $=24 \mathrm{ml}$ ) equilibrated with 20 $\mathrm{mM}$ sodium acetate buffer $(\mathrm{pH} 4.6)$ and eluted with the same buffer at $0.5 \mathrm{ml} / \mathrm{min}$. The purity of the toxic fraction was evaluated by SDS-PAGE.

\section{Protein estimation and electrophoresis.}

Protein concentration was determined by the method of Lowry et al. (1951). PAGE was run under denaturing conditions with SDS. This was carried out with the buffer system of Fling and Gregerson (1986) at $\mathrm{pH} 8.5$ with a $10 \%$ separating gel and $5 \%$ stacking gel. Samples of the toxin and protein molecular weight markers (Bio-Rad Canada, Mississauga, Canada) were prepared in sample buffer $(10 \mu \mathrm{l})$ consisting of $0.2 \mathrm{M}$ Tris- $\mathrm{HCl}$, $\mathrm{pH} 8.8,0.5 \mathrm{M}$ sucrose, $0.01 \%$ bromophenol blue, and $10 \mathrm{mM}$ EDTA. To this were added $2.5 \mu \mathrm{l}$ of $10 \%$ SDS and $1 \mu \mathrm{l}$ of 0.25 $M$ dithiothreitol (DTT). Samples were heated for $5 \mathrm{~min}$ at $100^{\circ} \mathrm{C}$ and cooled on ice. After cooling, $2.5 \mu \mathrm{l}$ of $0.5 \mathrm{M}$ iodoacetamide was added and the samples allowed to stand for 15 min before loading onto a 0.75 -mm-thick mini-gel. After running $(1 \mathrm{~h}$ at $100 \mathrm{~V})$, the mini-gel was fixed for $15 \mathrm{~min}$ in methanol-acetic acid-water (5:1:5), stained with Coomassie brilliant blue $(0.05 \% \mathrm{wt} / \mathrm{vol}$ in fix solution) for $1 \mathrm{~h}$, and destained in methanol-acetic acid-water (2:0.8:7.2, vol:vol:vol).

\section{Molecular mass determination, amino acid composition, and sequence.}

The molecular mass of Ptr ToxB was determined by matrixassisted laser desorption/ionization time-of-flight mass spectrometry (MALDI-TOFMS). Spectra were obtained from samples deposited onto non-porous, ether-type polyurethane membranes as described by McComb et al. (1997). Amino acid analysis was conducted on an Applied Biosystems (Foster City, CA) model 420A amino acid derivatizer-analyzer, after manual hydrolysis. Amino acid sequencing was carried out on an Applied Biosystems model 475A gas-phase sequencer.

\section{Thermal stability.}

The heat stability of Ptr ToxB was determined by incubating $500-\mu \mathrm{l}$ samples of toxin $(9.5 \mu \mathrm{g}$ of protein per $\mathrm{ml})$ at 30 , $40,55,80$, and $100^{\circ} \mathrm{C}$ for 30 - and 60 -min periods. After heat treatment, the samples were allowed to cool to room temperature and then bioassayed for toxic activity.

\section{Effect of toxin concentration on toxic activity.}

A stock solution of the purified toxin $(0.95 \mathrm{mg}$ of protein per $\mathrm{ml}$ ) was serially diluted with distilled water to give dilutions of $10^{-1}, 10^{-2}, 10^{-3}, 10^{-4}$, and $10^{-5}$. The various dilutions were then bioassayed for toxic activity.

\section{ACKNOWLEDGMENTS}

We would like to thank R. Hill and D. Durnin for use of the FPLC, and I. Silva-Cardenas and R. Kowatsch for technical assistance. We are also indebted to H. Perrault and M. McComb of the Chemistry Department, University of Manitoba, for conducting the mass spectrometry work, and to S. Kielland of the Department of Biochemistry and Microbiology, University of Victoria, for carrying out the amino acid analysis. Financial support provided by a University of Manitoba Graduate Fellowship (to S. E. S.) and the National Science and Engineering Research Council of Canada (to L. L.).

\section{LITERATURE CITED}

Ballance, G. M., Lamari, L., and Bernier, C. C. 1989. Purification and characterization of a host- selective toxin from Pyrenophora triticirepentis. Physiol. Mol. Plant Pathol. 35:203-213.

Ballance, G. M., Lamari, L., Kowatsch, R., and Bernier, C. C. 1996. Cloning, expression and occurrence of the gene encoding the Ptr necrosis toxin from Pyrenophora tritici-repentis. Mol. Plant Pathol. OnLine, publication/1996/1209ballance.

Ciuffetti, L. M, Tuori, R. P., and Gaventa, J. M. 1997. A single gene encodes a selective toxin causal to the development of tan spot of wheat. Plant Cell 9:135-144.

Dhingra, O. D., and Sinclair, J. B. 1986. Culture media and their formulations. Pages 285-315 in: Basic Plant Pathology Methods. CRC Press, Boca Raton, FL.

Fling, S. P., and Gregerson, D. S. 1986. Peptide and protein molecular weight determination by electrophoresis using a high-molarity Tris buffer system without urea. Anal. Biochem. 155:83-88.

Hagborg, W. A. F. 1970. A device for injecting solutions and suspensions into thin leaves of plants. Can. J. Bot. 48:1135-1136.

Haurowitz, F. 1963. The Chemistry and Function of Proteins. 2nd ed. Academic Press, New York.

Hosford, R. M., Jr. 1982. Tan spot. Pages 1-24 in: Tan Spot of Wheat and Related Diseases. R. M. Hosford, Jr., ed. North Dakota State University, Fargo.

Lamari, L., and Bernier, C. C. 1989a. Evaluation of wheat lines and cultivars to tan spot (Pyrenophora tritici-repentis) based on lesion type. Can. J. Plant Pathol. 11:49-56.

Lamari, L., and Bernier, C. C. 1989b. Virulence of isolates of Pyrenophora tritici-repentis on 11 wheat cultivars and cytology of the differential host reactions. Can. J. Plant Pathol. 11:284- 290.

Lamari, L., and Bernier, C. C. 1989c. Toxin of Pyrenophora triticirepentis: Host-specificity, significance in disease, and inheritance of host reaction. Phytopathology 79:740-744.

Lamari, L., and Bernier, C. C. 1991. Genetics of tan necrosis and extensive chlorosis in tan spot of wheat caused by Pyrenophora triticirepentis. Phytopathology 81:1092-1095.

Lamari, L., Sayoud, R., Boulif, M., and Bernier, C. C. 1995. Identification of a new race in Pyrenophora tritici-repentis: implications for the current pathotype classification system. Can. J. Plant Pathol. 17:312318.

Lowry, O. H., Rosebrough, N. J., Farr, A. L., and Randall, R. J. 1951. Protein measurement with the Folin phenol reagent. J. Biol. Chem. 193:265-275.

McComb, M. E., Oleschuk, R. D., Manley, D. M., Donald, L., Chow, A., O'Neil, J. D. J., Ens, W., Standing, K. G., and Perrault, H. 1997. Use of a non-porous polyurethane membrane as a sample support for matrix-assisted desorption/ionization time-of-flight mass spectrometry of peptides and proteins. Rapid Comm. Mass Spectrom. 11:1716-1722.

Orolaza, N. P., Lamari, L., and Ballance, G. M. 1995. Evidence of a host-specific chlorosis toxin from Pyrenophora tritici-repentis, the causal agent of tan spot of wheat. Phytopathology 85:1282-1287.

Strelkov, S. E., Lamari, L., Ballance, G. M., and Orolaza, N. P. 1998. Isolation and mode of action of the Ptr chlorosis toxin from Pyrenophora tritici-repentis. Pages 137-138 in: Molecular Genetics of HostSpecific Toxins in Plant Disease. K. Kohmoto, and O. C. Yoder, eds. Kluwer Academic Pub., Dordrecht, The Netherlands.

Tomás, A., and Bockus, W. W. 1987. Cultivar-specific toxicity of culture filtrate of Pyrenophora tritici-repentis. Phytopathology 77:13371340.

Tuori, R. P., Wolpert T. J., and Ciuffetti, L. M. 1995. Purification and immunological characterization of toxic components from cultures of Pyrenophora tritici-repentis. Mol. Plant-Microbe Interact. 8:41-48.

Walton, J. D. 1996. Host-selective toxins: agents of compatibility. Plant Cell 8:1723-1733. 